\title{
Effect of nitrate and ammonium on the growth and protein concentration of Microcystis viridis Lemmermann (Cyanobacteria)
}

\author{
GABRIELA VON RÜCKERT ${ }^{1}$ and ALESSANDRA GIANI ${ }^{1,2}$
}

(received: April 2, 2003; accepted: February 5, 2004)

\begin{abstract}
Effect of nitrate and ammonium on the growth and protein concentration of Microcystis viridis Lemmermann (Cyanobacteria)). Cyanobacteria are a very important group in aquatic systems, particularly in eutrophic waters. Therefore studies about their success in the environment are essential. Many hypotheses have tried to explain the dominance of Cyanobacteria, and several emphasized the importance of various nitrogen sources for the success of the group. In this study, we measured the effect of ammonium and nitrate on the growth and protein concentration of Microcystis viridis (Cyanobacteria). This species is well-known because bloom formation in eutrophic waters. The study was carried out, in experimental batch cultures, using the WC medium with different nitrogen sources: ammonium, nitrate, ammonium + nitrate (50\% ammonium $+50 \%$ nitrate) and ammonium at different concentrations (to test for possible $\mathrm{NH}_{4}{ }^{+}$toxicity). Protein, ammonium and nitrate concentrations were measured at end of each experiment, whereas samples for cell counts were taken daily. Results showed that Microcystis viridis grew faster with ammonium $\left(\mu=0.393\right.$ day $\left.^{-1}\right)$ than with nitrate $\left(\mu=0.263\right.$ day $\left.^{-1}\right)$ and ammonium + nitrate $\left(\mu=0.325\right.$ day $\left.^{-1}\right)$. This pattern is explained by the metabolism of ammonium that presents higher uptake and assimilation rates than nitrate. Maximum cell concentration, however, was higher in the ammonium + nitrate treatment, followed by nitrate treatment. Higher protein concentration were observed in the treatment with nitrate. In the ammonium toxicity test, no difference between the control and $\mathrm{NH}_{4}^{+}$at $50 \%$ was found. Thus, the ammonium concentrations used in these experiments were not toxic. Our results suggest that Cyanobacteria is able to grow on both nitrogen sources even if ammonium may allow faster growth and bloom development.
\end{abstract}

Key words - ammonium, Cyanobacteria, eutrophication, growth, nitrate, protein concentration

RESUMO - (Efeito do nitrato e amônio sobre o crescimento e a concentração de proteínas de Microcystis viridis Lemmermann (Cyanobacteria)). As cianobactérias são um grupo muito importante em sistemas aquáticos, particularmente nos sistemas eutrofizados. Por isso, estudos sobre o sucesso desse grupo são essenciais. Muitas hipóteses têm tentado explicar a dominância de Cyanobacteria e várias enfatizam a importância de fontes nitrogenadas para o sucesso delas. Neste estudo, foi avaliado o efeito dos íons amônio e nitrato sobre o crescimento e a concentração protéica de Microcystis viridis (Cyanobacteria). Esta espécie é bem conhecida por apresentar florações em águas eutróficas. O estudo foi conduzido em culturas do tipo "batch", usando o meio WC com diferentes fontes nitrogenadas: amônio, nitrato, amônio + nitrato (50\% amônio + 50\% nitrato), e amônio em diferentes concentrações (para testar o possível efeito tóxico de $\mathrm{NH}_{4}^{+}$). Amostras para contagem celular foram retiradas diariamente. As concentrações de proteína, amônio e nitrato foram medidas ao final dos experimentos. Os resultados mostraram que Microcystis viridis cresceu mais rápido com amônio $\left(\mu=0,393\right.$ dia $\left.^{-1}\right)$ comparado com nitrato $\left(\mu=0,263\right.$ dia $\left.^{-1}\right)$ e amônio + nitrato $\left(\mu=0,325 \mathrm{dia}^{-1}\right)$. Isso é explicado pelo metabolismo do amônio, que apresenta taxas de absorção e de assimilação maiores que as encontradas para nitrato. A concentração celular máxima, entretanto, foi maior no tratamento amônio + nitrato, seguido pelo tratamento nitrato. A maior concentração de proteínas foi observada no tratamento nitrato. No teste de toxicidade, nenhuma diferença entre o controle $\mathrm{e} \mathrm{NH}_{4}{ }^{+}$a $50 \%$ foi encontrada. Logo, as concentrações de amônio utilizadas nos experimentos não foram tóxicas. Nossos resultados sugerem que Cyanobacteria é capaz de crescer com ambas fontes nitrogenadas, mesmo considerando que o amônio permite um crescimento mais rápido e o desenvolvimento de florações.

Palavras-chave - amônio, Cyanobacteria, concentração protéica, crescimento, eutrofização, nitrato

\section{Introduction}

Phytoplankton seasonal succession is largely controlled by the concentration of nutrients available in the environment, because of their wide variations in time

1. Universidade Federal de Minas Gerais, Instituto de Ciências Biológicas, Departamento de Botânica, Caixa Postal 486, 31270-110 Belo Horizonte, MG, Brazil.

2._Corresponding author: agiani@icb.ufmg.br and space and of the species different requirements. Therefore, the population growth depends on the possibility of one or more nutrients to be available. Thus, the algal growth may be limited, saturated or in some cases inhibited by one particular nutrient (Reynolds 1984).

Nitrogen is a nutrient that can limit phytoplankton production in natural waters. Nitrate, nitrite and ammonium ions and many dissolved organic nitrogenous compounds (urea, free amino-acids and peptides) are 
the main sources of nitrogen for the algae, used mainly for the synthesis of amino-acids and proteins (Reynolds 1984).

Ammonium is the inorganic nitrogenous form of easier assimilation, since nitrate and nitrite first have to be reduced to ammonium before assimilation. The assimilation process is done throughout the ATPdependent glutamine synthetase (GS) and ferrodoxindependent glutamate synthethase (GOGAT) enzyme system. Nitrate is first reduced to nitrite and then to ammonium. In Cyanobacteria the reduction process from nitrate to nitrite is catalyzed by the nitrate reductase enzyme that usually uses two ferrodoxins as electrons donors. The reduction from nitrite to ammonium is catalyzed by the nitrite reductase, process that needs six ferrodoxins. The full process consumes 8 ferrodoxins. (Syrett 1981, Lara et al. 1987). The ammonium availability directly interferes in the uptake of the other nitrogen sources. Syrett (1981), demonstrated the interference of ammonium in nitrate uptake, when both are available in batch cultures, by showing the preferential uptake of ammonium and its inhibition on the activation of the nitrate reductase and consequently on the nitrate uptake system.

The eutrophication process increases nutrient availability and primary production, and it also results in changes in the phytoplankton species composition. Generally, an increase in the Cyanobacteria population can be observed in eutrophic systems (Ahlgren 1977).

Nitrate, nitrite and ammonium are all used as inorganic source of nitrogen by the Cyanobacteria, so as $\mathrm{N}_{2}$ from $\mathrm{N}$-fixing cyanobacteria. But when ammonium is available, it seems that these organisms do not assimilate others inorganic source of nitrogen (Ochoa-de-Alda et al. 1996).

Blomqvist et al. (1994) observed that, in the presence of elevated "ammonium pools" or high ammonium turnover rates the growth of no-N-fixing cyanobacteria was improved. Therefore, the eucaryotic phytoplankton grews better with nitrate, and "nitrate pools" repress the competitive ability of blue-green algae in mixed communities.

In Pampulha reservoir (Belo Horizonte, Brazil), a tropical eutrophic urban system, blooms of cyanobacteria occur periodiocally during some periods of the year (Giani 1994, Pinto-Coelho 1998, Giani \& Figueredo 1999, Figueredo \& Giani 2001). At this time, the cyanobacterium Microcystis viridis Lemmermann can be dominant in the reservoir and may represent up to 93\% of the total phytoplankton biomass (Figueredo \& Giani 2001). In Pampulha reservoir, Cyanobacteria blooms are associated to periods of water column stability and nutrients abundance, both usually observed during the dry season (Giani \& Figueredo 1999). Goodwin (1997) detected a negative correlation between nitrate $\left(\mathrm{N}^{-} \mathrm{NO}_{3}^{-}\right)$and cyanobacteria density in Pampulha reservoir. Former field observations also showed a decrease in nitrate concentration previously to the bloom development (A. Giani, unpublished data).

Considering the importance of nitrogen sources for the phytoplankton development and the recurrence of Cyanobacteria in Pampulha reservoir, the objective of this study was to compare the growth of an isolated strain of Microcystis viridis, the most abundant cyanobacteria during bloom periods, on different nitrogen sources (nitrate and ammonium), to verify their effects on cellular growth and protein production.

\section{Material and methods}

The cyanobacterium Microcystis viridis Lemmermann (figure 1, for details see Giani et al. 1999), was isolated from Pampulha reservoir (Belo Horizonte, Brazil) and was maintained in culture in the Laboratory of Phycology of the Universidade Federal de Minas Gerais (UFMG). The experimental conditions were: $20^{\circ} \mathrm{C}$ temperature, $12: 12 \mathrm{~L} / \mathrm{D}$ period and irradiance of $60 \mu \mathrm{mol} \cdot \mathrm{m}^{-2} \cdot \mathrm{s}^{-1}$. WC (Guilhard \& Lorenzen 1972) was used as culture medium. The original $\mathrm{NaNO}_{3}$, used as nitrate source, was replaced by $\mathrm{NH}_{4} \mathrm{Cl}$, as ammonium source in the ammonium experiments.

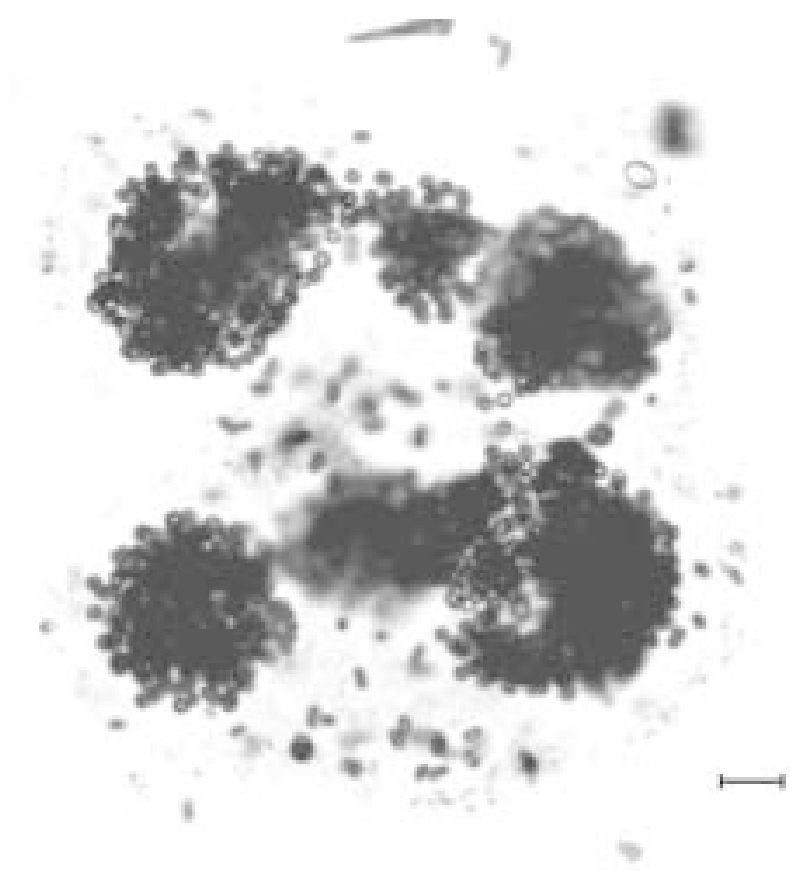

Figure 1. Microcystis viridis colony. Bar $=20 \mu \mathrm{m}$. Microphotograph by C.C. Figueredo. 
Experiments were carried out in batch cultures. The treatments were applied as follows: 1) ammonium $\left.\left(6,900 \mu \mathrm{g} . \mathrm{L}^{-1}\right), 2\right)$ nitrate $\left.\left(7,000 \mu \mathrm{g} . \mathrm{L}^{-1}\right), 3\right)$ ammonium + nitrate $\left(3,450+3,500 \mu \mathrm{g} . \mathrm{L}^{-1}\right)$ and 4$)$ ammonium at different concentrations (control: 6,900 $\mu \mathrm{g} . \mathrm{L}^{-1}$ and 50\%: 3,450 $\mu \mathrm{g} . \mathrm{L}^{-1}$ ). The treatments were run in duplicate or triplicate and results are here represented as mean values. All experiments have been repeated and showed the same tendencies presented in results. In this paper, for the treatments ammonium and nitrate $\mathrm{n}=3$, and for ammonium + nitrate and toxicity test $\mathrm{n}=2$.

Samples for cell counts were taken daily at the same time schedule and preserved with lugol solution. Around 400 cells/sample ( $\pm 10 \%$ precision within $95 \%$ confidence limits) were counted in a Neubauer hemocytometer. Samples of $M$. viridis were previously sonified in order to break up colonies and improve the cells quantification.

At the end of the experiments, cultures were filtered through glass fiber filter (GF/C type). These filters were used to estimate protein concentration using the micro-biuret method (Itzhaki \& Gill 1962) and the dry weight. Final concentrations of nitrate and ammonium were measured in the filtrate by spectophotometric methods (Golterman et al. 1978, Chaney \& Marbach 1962).

In the treatment ammonium+nitrate, both ammonium and nitrate were available in concentrations corresponding to $50 \%$ of the original medium. Six cultures were maintained, and every five days, two of them were harvested, then filtered, to obtain final concentrations of intracellular protein, and ammonium and nitrate in the medium.

To verify the possible toxic effect of the ammonium concentration of the medium on the growth of M. viridis, another experiment was developed where ammonium was reduced to $50 \%$ of the original concentration. The experiment ran for seven days. Samples for cell count and for measurement of the ammonium concentration were taken at first and last day.

For each treatment, we calculated the intrinsic rate of growth $(\mu)$ through a linear regression of the growth curves in the exponential phase (Systat for Windows - version 5), where $\mu$ correspond to the coefficient of $x$ in the linear equation, and $y$ is the ln of the cells' number.

A co-variance analysis (Systat for Windows - version 5) was used to compare the growth pattern between the treatments. The slopes of the growth curves were compared. The differences were significant if $\mathrm{P}<0.05$.

\section{Results}

Cell counts provided cell density, growth curves and the respective intrinsic rate of growth $(\mu)$, for the treatments with ammonium, nitrate and ammonium + nitrate (figure 2). In the ammonium treatment (figure 2A, B), M. viridis presented a faster growth than with nitrate. The exponential growth lasted approximately 6

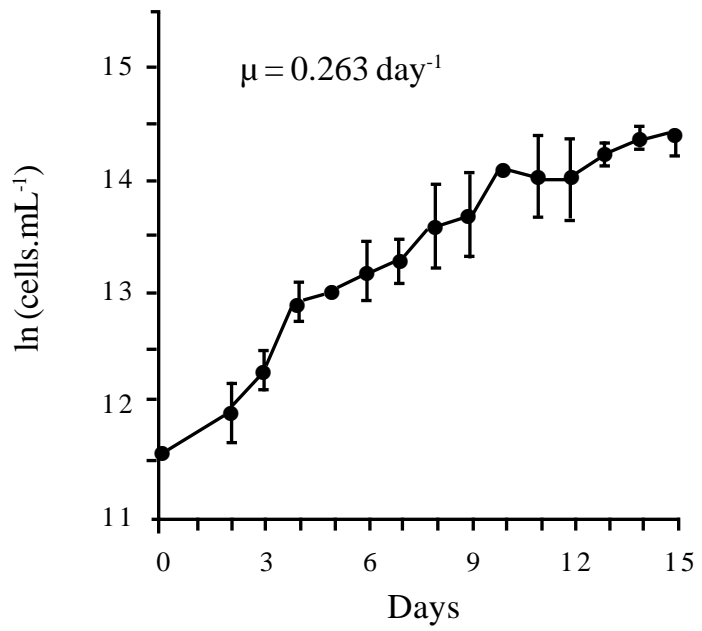

A

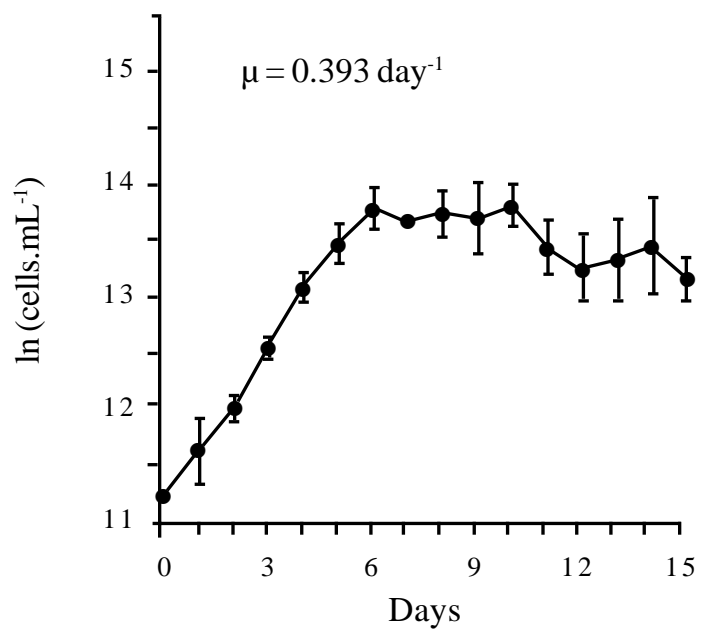

B

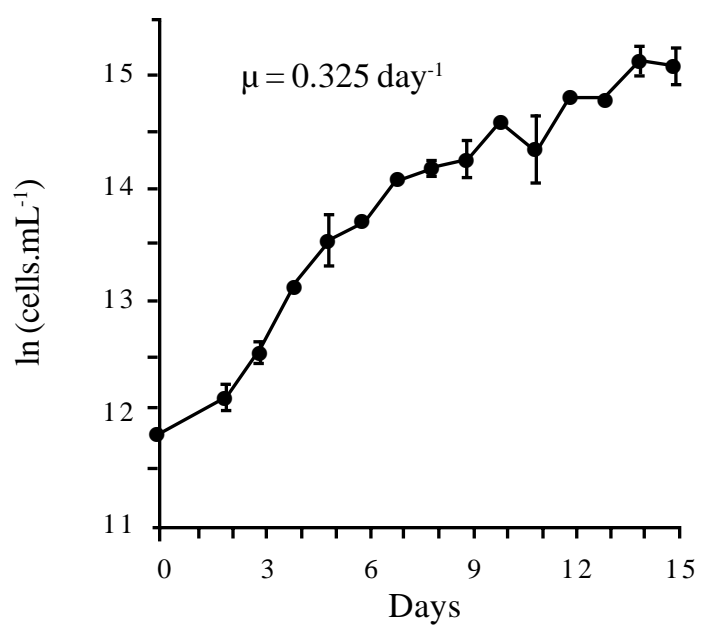

C

Figure 2. Growth of Microcystis viridis in nitrate (A), ammonium (B) and ammonium + nitrate (C) treatments. Mean and standard-deviation, $\mathrm{n}=3$ for $\mathrm{NO}_{3}^{-}$and $\mathrm{NH}_{4}^{+} ; \mathrm{n}=2$ for $\mathrm{NO}_{3}^{-}+\mathrm{NH}_{4}^{+}$. 
days and the intrinsic rate of growth $(\mu)$ was 0.393 day $^{-1}$. In the nitrate treatment (figure $2 \mathrm{~B}$ ) $\mu$ was lower: 0.263 day $^{-1}$ and the steady state was reached later. However, the nitrate medium supported higher cell density than the ammonium (table 1). Significant differences were observed between the growth patterns in the ammonium and nitrate treatments by co-variance analysis between slopes $(\mathrm{P}=0.001)$.

Table 1. Average cell densities (cells. $\mathrm{mL}^{-1}$ ) - initial, final and maximum - in the nitrate, ammonium and ammonium + nitrate treatments.

\begin{tabular}{lccc}
\hline & $\begin{array}{c}\mathrm{NO}_{3}^{-} \\
(\mathrm{n}=3)\end{array}$ & $\begin{array}{c}\mathrm{NH}_{4}^{+} \\
(\mathrm{n}=3)\end{array}$ & $\begin{array}{c}\mathrm{NH}_{4}^{+}+\mathrm{NO}_{3}^{-} \\
(\mathrm{n}=2)\end{array}$ \\
\hline Initial & $1.12 \times 10^{5}$ & $7.30 \times 10^{4}$ & $1.36 \times 10^{5}$ \\
Final & $1.78 \times 10^{6}$ & $5.72 \times 10^{5}$ & $3.59 \times 10^{6}$ \\
Maximum & $1.78 \times 10^{6}$ & $1.11 \times 10^{6}$ & $3.74 \times 10^{6}$ \\
\hline
\end{tabular}

The growth curve of the ammonium + nitrate treatment showed an intermediary pattern (figure 2C). Cell grew fast until the $6^{\text {th }}-7^{\text {th }}$ day, and the $\mu$ $\left(0.325\right.$ day $\left.^{-1}\right)$ was similar to treatment with ammonium. From the $8^{\text {th }}-9^{\text {th }}$ day, growth continued slower and steady state seemed to begin only at the end of the experiment $\left(15^{\text {th }}\right.$ day). The treatment ammonium + nitrate showed significant differences in comparison with ammonium alone $(\mathrm{P}<0.001)$. Nitrate treatment was significantly different only at $\mathrm{P}<0.1$. Maximum cell concentration was higher than in the ammonium and in the nitrate treatment $-3.74 \times 10^{6}$ cells. $\mathrm{mL}^{-1}$ (table 1 ).

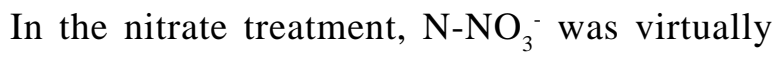
depleted (table 2), whereas $\mathrm{N}-\mathrm{NH}_{4}{ }^{+}$was still available at the end of the experiment in the ammonium treatment. For this reason, lower cell densities in the ammonium treatment could not be due to $\mathrm{N}-\mathrm{NH}_{4}^{+}$limitation. The concentrations of nitrogen in the treatment with ammonium + nitrate, $\mathrm{N}-\mathrm{NH}_{4}{ }^{+}$and $\mathrm{N}-\mathrm{NO}_{3}{ }^{-}$were estimated every 5 days (table 3 ), showed that ammonium

Table 2. Average final concentrations (as $\%$ of the initial concentration) of $\mathrm{N}^{-\mathrm{NO}_{3}}{ }^{-}$or $\mathrm{N}-\mathrm{NH}_{4}^{+}$in ammonium and nitrate treatments.

\begin{tabular}{ccc}
\hline & $\begin{array}{c}\mathrm{NO}_{3}^{-} \\
(\mathrm{n}=3)\end{array}$ & $\begin{array}{c}\mathrm{NH}_{4}^{+} \\
(\mathrm{n}=3)\end{array}$ \\
\hline $\mathrm{N}^{+} \mathrm{NO}_{3}^{-}$ & 2.5 & 0.0 \\
$\mathrm{~N}^{-}$ & 0.0 & 45.8 \\
\hline
\end{tabular}

Table 3. Average concentrations (as \% of the initial concentration) of $\mathrm{N}^{-\mathrm{NO}_{3}}{ }_{3}^{-}$and $\mathrm{N}-\mathrm{NH}_{4}{ }^{+}$in the ammonium + nitrate treatment on the $5^{\text {th }}, 10^{\text {th }}$ and $15^{\text {th }}$ day.

\begin{tabular}{rcc}
\hline Day & $\begin{array}{r}\mathrm{N}^{-N_{3}}{ }_{3}^{-} \\
(\mathrm{n}=2)\end{array}$ & $\begin{array}{c}\mathrm{N}^{-} \mathrm{NH}_{4}^{+} \\
(\mathrm{n}=2)\end{array}$ \\
\hline 5 & 45.3 & 48.0 \\
10 & 37.5 & 0.0 \\
15 & 1.5 & 0.0 \\
\hline
\end{tabular}

was depleted on the $10^{\text {th }}$ day, while nitrate was still available. The final protein concentration (figure 3), in the nitrate treatment, was always higher than in the ammonium and ammonium + nitrate treatments $\left(717 \mu \mathrm{g} . \mu \mathrm{g} \mathrm{DW}-1-\mathrm{NO}_{3}, 580 \mu \mathrm{g} . \mu \mathrm{g} \mathrm{DW} \mathrm{DW}^{-1}-\mathrm{NH}_{4}^{+}\right.$and $378 \mu \mathrm{g} . \mu \mathrm{g} \mathrm{DW}{ }^{-1}-\mathrm{NH}_{4}^{+}+\mathrm{NO}_{3}^{-}$). In the treatment ammonium + nitrate, the protein concentration increased along the experiment (figure 4). In the ammonium toxicity test, both control and $50 \% \mathrm{NH}_{4}^{+}$presented similar final cell densities (table 4). Uptake of $\mathrm{N}^{-\mathrm{NH}_{4}{ }^{+}}$ was similar for both concentrations (table 5). The ammonium concentration used in our experiments has probably no toxic effect on the growth of $M$. viridis.

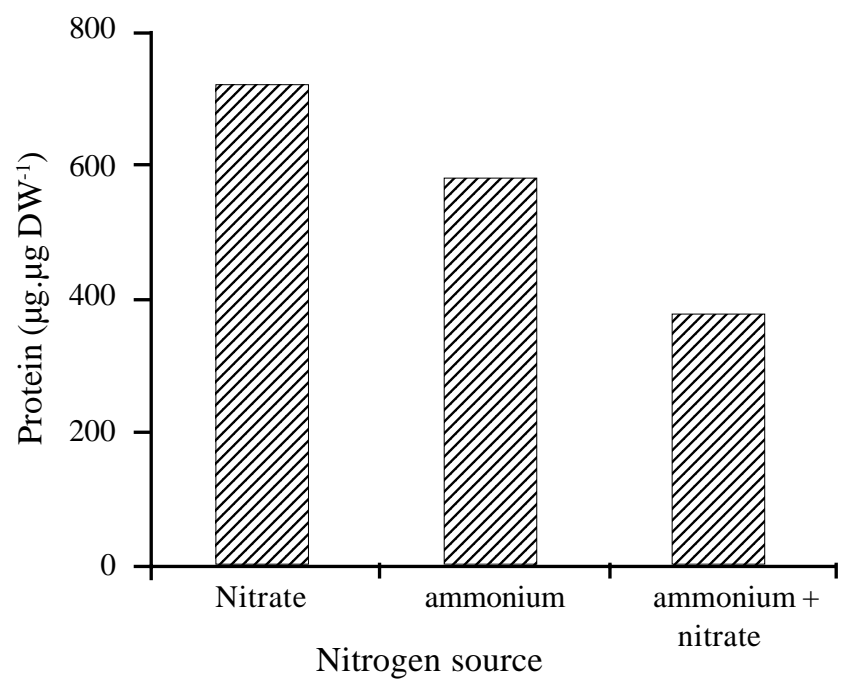

Figure 3. Final proteins concentrations $\left(\mu \mathrm{g} . \mu \mathrm{g} \mathrm{DW}^{-1}\right)$ in ammonium, nitrate and ammonium + nitrate treatments.

\section{Discussion}

Freshwater systems can become nitrate depleted after periods of intensive algal growth, specially when thermal stability retains nutrients in the hypolimnion (Reynolds 1984). Under such anoxic conditions, nitrate 


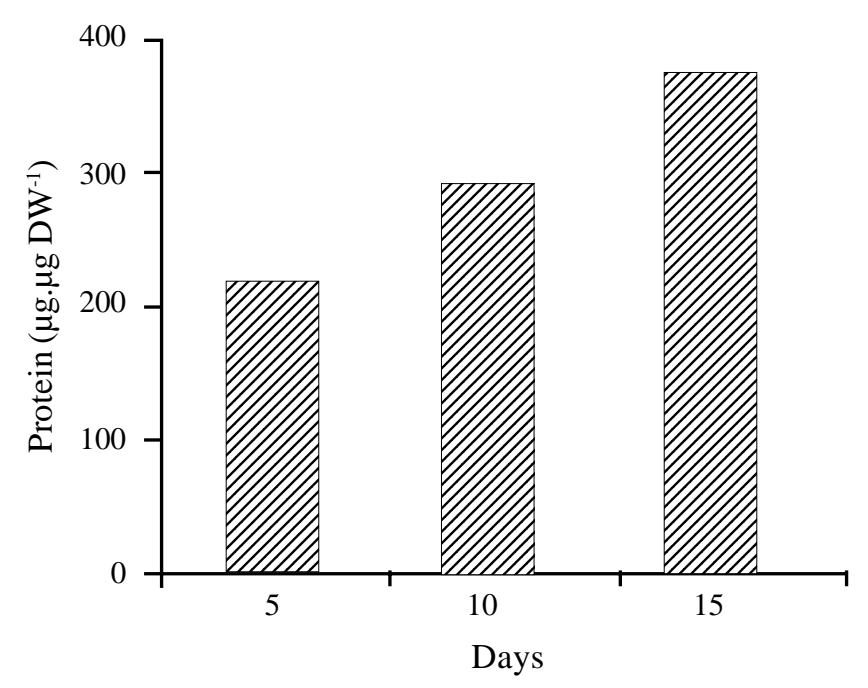

Figure 4. Protein concentrations $\left(\mu \mathrm{g} . \mu \mathrm{g} \mathrm{DW} \mathrm{DW}^{-1}\right)$ in ammonium + nitrate treatment on the $5^{\text {th }}, 10^{\text {th }}$ and $15^{\text {th }}$ days.

Table 4. Average cells densities (cell. $\mathrm{mL}^{-1}$ ) - initial and final in the toxicity treatment.

\begin{tabular}{lcc}
\hline & $\begin{array}{c}\text { Control } \\
(\mathrm{n}=2)\end{array}$ & $\begin{array}{c}50 \% \\
(\mathrm{n}=2)\end{array}$ \\
\hline Initial & $1.10 \times 10^{5}$ & $1.19 \times 10^{5}$ \\
Final & $1.27 \times 10^{6}$ & $1.08 \times 10^{6}$ \\
\hline
\end{tabular}

Table 5. Average concentrations of $\mathrm{N}-\mathrm{NH}_{4}{ }^{+}\left(\mu \mathrm{g} . \mathrm{L}^{-1}\right)$ - initial, final and amount absorved - in the toxicity test treatment.

\begin{tabular}{lcr}
\hline & $\begin{array}{c}\text { Control } \\
(\mathrm{n}=2)\end{array}$ & $\begin{array}{r}50 \% \\
(\mathrm{n}=2)\end{array}$ \\
\hline Initial & $6,953.1$ & $2,865.4$ \\
Final & $4,178.5$ & 840.4 \\
Absorbed & $2,775.3$ & $2,025.0$ \\
\hline
\end{tabular}

is reduced to ammonium. In temperate systems, this can be frequently noticed after the algal summer maximum. In tropical lakes, nitrogen deficiency has already been discussed and seems to be connected with high internal losses like denitrification (Dowining et al. 1999, Lewis 2002). Conditions favorable to denitrification may be more probable in tropical than in temperate lakes. In Pampulha reservoir, during the dry and colder winter months phytoplankton peaks with maximal densities of green algae and flagellates are observed (Giani \& Figueredo 1999). Later in spring when temperature increases, the system becomes stratified and nitrate becomes depleted from the euphotic zone. At this moment, cyanobacteria blooms occur (Giani 1994, Goodwin \& Giani 1998).

Among phytoplankton species, cyanobacteria are known to be better competitors for nitrogen (Tilman et al. 1986, Michard et al. 1996, Giani \& Delgado 1997). Furthermore, Blomqvist et al. (1994) observed that the suppression of nitrate pools improve the competitive ability for ammonium nitrogen of these organisms in comparison to most eucariotic algae. Under low nitrate concentrations one would expect the dominance of nonnitrogen-fixing species, like Microcystis species. This is exactly what was observed in Pampulha reservoir, since Cyanobacteria blooms occur when ammonium concentrations are very high and nitrate not detectable. Goodwin (1997) observed in this reservoir a negative relationship between the abundance of $M$. viridis and the nitrate concentration in the water. The author did not find, however, any relationship with ammonium concentration.

Uptake and assimilation rates for ammonium are normally higher than for nitrate, because no enzymatic reduction is required for ammonium assimilation (McCarthy et al. 1982, Dortch \& Postel 1989a, Mallet et al. 1998). This also means lower energetic costs because of the consumption of 8 ferrodoxins by the cyanobacteria to reduce nitrate to ammonium (Syrett 1981, Lara et al. 1987). Once nitrate is absorbed, accumulates in the cell or is reduced to intermediate compounds, such as ammonium and free amino acids, before it becomes incorporated into protein and chlorophyll, and cell division starts (Dortch \& Postel 1989b). Therefore, the growth of a phytoplankton population could be slower with nitrate than with ammonium. Higher values of the intrinsic rate of growth $(\mu)$ found in our experiments in the treatment with ammonium $\left(\mu=0.393\right.$ day $\left.^{-1}\right)$ and ammonium + nitrate $\left(\mu=0.325\right.$ day $\left.^{-1}\right)$ can be a consequence of higher uptake and assimilation rates on ammonium when compared to nitrate $\left(\mu=0.263\right.$ day $\left.^{-1}\right)$. Paasche (1971) also found that growth of the green alga Dulaniella tertiolecta was $10 \%-30 \%$ more rapid under ammonium than under nitrate conditions.

In our experiment, higher cell density and protein content were found in the treatments with nitrate and ammonium + nitrate. Phytoplankton accumulates intracellular nitrogen in the form of a variety of compounds, such as nitrate, ammonium, amino-acids, proteins, RNA and pigments. These compounds serve as a long-term nitrogen storage reservoir (Dortch et al. 
1984). Dortch et al. (1984) found that the amount of protein in algal cells is variable. When growing on $\mathrm{NO}_{3}^{-}$ in comparison with $\mathrm{NH}_{4}^{+}$, some species presented higher protein concentration in the cells. Protein loss is generally a result of nitrogen starvation. In our experiments, Microcystis viridis could have been N-limited when growing on $\mathrm{NH}_{4}^{+}$. Ammonium concentration in the growth medium, however, did not seem to be limiting, because it was not completely harvested at the end of the experiment, opposite to nitrate, that was entirely consumed. It is possible that the cyanobacteria take advantage over other phytoplanktonic species through their ability to uptake ammonium. Their maximal cell density, however, can be achieved under higher nitrate conditions.

Dortch et al. (1984) also observed that the proteins associated with the chlorophyll-protein complex decreased in nitrogen starved cultures. Smit et al. (1997) reported a positive relationship between protein and chlorophyll $a$. Chlorophyll $a$ is one of the most important nitrogen pool in algae: the pigment may reduce nitrogen limitation. In some groups, as in cyanobacteria, where proteins are also associated with the biliproteins (Stanier 1977), these pigments may account for $40 \%$ to $50 \%$ of the total cell protein. We observed that cultures growing under $\mathrm{NH}_{4}{ }^{+}$conditions presented lower pigment content and a yellow green color in all experiments, and, in comparison, nitrate cultures showed an intense blue green color.

It is also possible that Cyanobacteria contribute to maintain undectable nitrate levels in the upper layers of water column by the uptake of most nitrate, that has been produced by the oxidation of ammonium present at very high concentration in the reservoir. Several studies indicated that nitrate uptake suffers inhibition by the presence of ammonium (McCarthy et al. 1982, Mitamura et al. 1995, Tang et al. 1997, Sakamoto \& Bryant 1999). When ammonium and nitrate are both present, ammonium is generally preferred, although the complete suppression of the nitrate uptake is rare (Syrett 1981). The magnitude of the inhibition varies according to the ammonium concentration, the nutrient prehistory, the metabolic state of the organism and perhaps some environmental variable such as light (Syrett 1981, Dortch \& Postel 1989b). We could not observe inhibition of nitrate uptake in our ammonium + nitrate treatment. This confirm our hypothesis that $M$. viridis could be able to assimilate nitrate in the reservoir, even when ammonium is detected at very high concentration.

In summary, we observed that Microcystis viridis was able to attain similar cell densities growing on both ammonium and nitrate. Nevertheless when it was growing on ammonium, high biomass values (as cell number) were reached more rapidly, presumably because of the higher growth rate, thus driving to the conclusion that ammonium may lead or induce a population bloom. However, under nitrate conditions $M$. viridis could maintain a population of high cell densities for longer, showed higher protein content and was able to deplete nitrate from the medium. Therefore cyanobacteria may compete with eukaryotes for nitrate and also have better skills to the rapid use of ammonium when nitrate is no longer available in the environment, thus allowing them to suddenly increase their population and develop into a bloom.

Aknowledgements - This work was supported by CNPq and Fapemig research grants and a CNPq scholarship to $\mathrm{G}$. von Rückert.

\section{References}

AHLGREN, G. 1977. Growth of Oscillatoria agardhii in chemost culture - 1. Nitrogen and phosphorus requeriments. Oikos 29:209-224.

BLOMQVIST, P., PETTERSSON, A. \& HYENSTRAND, P. 1994. Ammonium - nitrogen: A key of non-nitrogenfixing cyanobacteria in aquatic systems. Archiv für Hydrobiologie 132:141-164.

CHANEY, A.L. \& MARBACK, E.P. 1962. Modified reagents for the determination of urea and amonia. Clinical Chemistry 8:130-132.

DORTCH, Q., CLAYTON JUNIOR, J.R., THORESEN, S.S. \& AHMED, S.I. 1984. Species differences in accumulation of nitrogen pools in phytoplankton. Marine Biology 81:237-250.

DORTCH, Q. \& POSTEL, J.R. 1989a. Biochemical indicators for $\mathrm{N}$ utilization by phytoplankton during upwelling off the Washington coast. Limnology and Oceanography 34:758-773.

DORTCH, Q. \& POSTEL, J.R. 1989b. Phytoplankton-Nitrogen interactions. In Coastal Oceanography of Washington and Oregon (M.R. Landry \& B.M. Hickey, eds.). Elsevier Science Publihers, Amsterdam, p.139-173.

DOWNING, J.A., MCCLAIN, M., TWILLEY, R., MELACK, J.M., ELSER J., RABALAIS, N.N., LEWIS JUNIOR, W.M., TURNER, R.E., CORREDOR, J., SOTO, D., YANEZ-ARANCIBIA, A., KOPASKA, J.A. \& HOWARTH, R.W. 1999. The impact of accelerating landuse change on the $\mathrm{N}$-Cycle of tropical aquatic ecosystems: current conditions and projected changes. Biogeochemistry 46:109-148.

FIGUEREDO, C.C. \& GIANI, A. 2001. Seasonal variation of the diversity and species richness of phytoplankton in a tropical reservoir. Hydrobiologia 445:165-174. 
GIANI, A. 1994. Limnology in Pampulha Reservoir: some general observations with emphasis on the phytoplankton community. In Ecology and human impact on lakes and reservoirs in Minas Gerais (R.M. Pinto-Coelho, A. Giani \& E. von Sperling, eds.). Segrac, Belo Horizonte, p.151-164.

GIANI, A. \& DELGADO, P.C.S. 1998. Growth dynamics and competitive ability of green (Oocystis lacustris) and a blue-green alga (Synechocystis sp.) under different N:P ratios. Verhein der Internationalen Vereinigung von Limnologie 26:1693-1697.

GIANI, A. \& FIGUEREDO, C.C. 1999. Recorrência de padrões sazonais do fitoplâncton num reservatório eutrófico (Reservatório da Pampulha, MG). In Ecologia de reservatório: estrutura, função e aspectos sociais (R. Henry, ed.). Fapesp / Fundbio, São Paulo / Botucatu, p.533-549.

GIANI, A., FIGUEREDO, C.C.\& ETEROVICK, P.C. 1999. Algas planctônicas do reservatório da Pampulha (MG): Euglenophyta, Chrysophyta, Pyrrophyta, Cyanobacteria. Revista Brasileira de Botânica 22:107-116.

GOLTERMAN, H.L., CLYMO, R.S. \& OHNSTAD, M.A.M. 1978. Methods for physical and chemical analyses of freshwaters. IBP Handbook 8. Blackwell Scientific Publications, London.

GOODWIN, K.L. 1997. Dinâmica das populações de Cyanobacteria no Reservatório da Pampulha (MG) em duas escalas temporais (sazonais e diurna). Dissertação de mestrado, Universidade Federal de Minas Gerais, Belo Horizonte.

GOODWIN, K.L. \& GIANI, A. 1998. Cyanobacteria in an eutrophic tropical reservoir: seasonal and vertical distribution. Verhein der Internationelen Vereinigung von Limnologie 26:1702-1706.

GUILLARD, R.R. \& LORENZEN, C.J. 1972. Yellow-green algae with chlorophyllidae $\mathrm{C}^{1,2}$. Journal of Phycology 8:10-14.

ITZHAKI, R.F. \& GILL, D.M. 1964. A micro-biuret method for estimating proteins. Analytical Biochemistry 9:401-410.

LARA, C., ROMERO, J.M., CORONIL, T. \& GUERRERO, M.G. 1987. Interactions between photosynthethic nitrate assimilation and $\mathrm{CO}_{2}$ fixation in Cyanobacteria. In Inorganic nitrogen metabolism (W.R. Ulrich, P.J. Aparicio, P.J. Syrett \& F. Castillo, eds.). Springer-Verlag, Berlin, p.45-52.

LEWIS JUNIOR, W.M. 2002. Causes for the high frequency of nitrogen limitation in tropical lakes. Verhein der Internationalen Vereinigung von Limnologie 28:210-213.

MALLET, C., CHARPIN, M.F. \& DEVAUX, J. 1998. Nitrate reductase activity of plankton populations in eutrophic Lake Aydat and meso-oligotrophic Lake Pavin: a comparison. Hidrobiologia 373/374:135-148.
MCCARTHY, J.J., WYNNE, D. \& BERMAN, T. 1982. The uptake of dissolved nitrogenous nutrients by Lake Kinneret (Israel) microplankton. Limnology and Oceanography 27:673-680.

MICHARD, M., ALEYA, L. \& VERNEAUX, J. 1996. Mass occurrence of the cyanobacteria Microcystis aeruginosa in the hypereutrophic Villrest Resevoir (Roanne, France): Usefulness of biyearly examination of N/P (nitrogen phosphorus) and $\mathrm{P} / \mathrm{C}$ (protein/ carbohydrate) couplings. Archiv für Hydrobiologie 135:337-359.

MITAMURA, O., SAIJO, Y., HINO, K. \& BARBOSA, F.A.R. 1995. The significance of regenerated nitrogen for phytoplankton productivity in the Rio Doce Valley Lakes, Brazil. Archiv für Hydrobiologie 134:179-194.

OCHOA-DE-ALDA, J.A.G., TAPIA, M.I., FRANCK, F., LLAMA, M.J. \& SERRA, J.L. 1996. Changes in nitrogen source modify distribution of excitation energy in the cyanobacterium Phormidium laminosum. Physiologia Plantarum 97:69-78.

PAASCHE, E. 1971. Effect of ammonia and nitrate on growth, photosynthesis and ribosediphosphate carboxylase content of Dunaliella tertiolecta. Physiologia Plantarum 25:294-299.

PINTO-COELHO, R.M. 1998. Eutrophication effects on seasonal patterns of mesoplankton in a tropical reservoir: a four years study in Pampulha Reservoir, Brazil. Freshwater Biology 40:159-173.

REYNOLDS, C.S. 1984. The ecology of freshwater phytoplankton - Cambridge studies in ecology. Cambridge University Press, Cambridge.

SAKAMOTO, T. \& BRYANT, D.A. 1999. Nitrate transport and not photoinhibition limits growth to freshwater cyanobacterium Synechococcus species PCC 6301 at low temperature. Plant Physiology 119:785-794.

SMIT, A.J., ROBERTSON, B.L. \& DU PREEZ, D.R. 1997. Influence of ammonium-N pulse concentrations and frequency, tank condition and nitrogen starvation on growth rate and bioquemical composition of Gracilaria gracilis. Journal of Applied Phycology 8:473-481.

STARNIER, R.Y. 1977. The position of cyanobacteria in the world of phototrophs. Carlsberg Research Communications 42:77-98.

SYRETT, P.J. 1981. Nitrogen metabolism of microalgae. In Physiological bases of phytoplankton ecology (T. Platt, ed.). Canadian Bulletin of Fisheries and Aquatic Sciences 210:182-210.

TANG, E.P.Y., VINCENT, W.F., PROULX, D., LESSARD, P. \& NOÜE, J. 1997. Polar cyanobacteria versus green algae for tertiary waste-water treatment in cool climates. Journal of Applied Phycology 9:371-381.

TILMAN, D., KIESLING, R., STERNER, R., KILHAM, S.S. \& JOHNSON, F.A. 1986. Green, bluegreen and diatom algae: taxonomic differences in competitive ability for phosphorus, silicon and nitrogen. Archiv für Hydrobiologie 106:473-485. 